of the elements of science and wedded to traditions that are now doomed is well portrayed, if rather exaggerated. That such a theme can find its place successfully on a London stage is significant of the fact that the importance of science as an unconscious revolutionary factor in society is beginning to be appreciated.

\section{Scientific Precision and Popularisation}

WHY is it that, in a certain class of publication aiming at popularity, vagueness seems to be considered essential in attracting the interest of the general public ? It appears particularly in relation to geographical and ethnographical details. We have before us two small volumes from a series with many pleasing features, "Things Seen by the Camera" (London: George Routledge and Sons, Ltd., price 2s. 6d. net each). Of these, each contains sixty-four photographic reproductions. One deals with China and the Chinese, and another with the natives of Africa. The latter is concerned exclusively with physical types and covers a fairly representative range, some evidently chosen to demonstrate peculiarities of dress or physical deformation, such as the distension produced by the woman's lip-ornament. The volume dealing with China, in addition to characteristic or peculiar types, includes scenes from Chinese life and examples of Chinese buildings and architecture. It often happens that material of this kind is collected by those who have lived in out-of-the-way parts of the world and are not in touch with scientific bodies. They put their material in the hands of agencies, which distribute it to the popular Press, but through inadequate description, material which might be of value to the scientific worker not infrequently loses its utility. In fairness to the two publications before us, it must be said that in most instances they give an approximate or precise attribution. But if in one case, why not in all? "Witch-doctor from Central Africa", "Native Girl from Rhodesia", says little. The popular attraction of the picture could not possibly be affected by the addition or omission of the name of the tribe in brackets.

\section{Britain's Contributions to World Progress}

IN a thoughtful essay entitled "The Projection of England" (London: Faber and Faber, Ltd., 1s.), Sir Stephen Tallents reminds us of our heritage of greatness in most fields of thought and activity, and points out that in the modern interdependence of nations, England can no longer afford to pursue a policy of standing aloof from the rest of the world. $\mathrm{He}$ indicates some of the attainments of the British in the fields of science and industry, and reflects that these are too little known to other nations. England neglects many opportunities of making herself known abroad, and of communicating her knowledge and discoveries to a wider world. In short, while he deprecates any form of national boasting, Sir Stephen Tallents argues that we need to develop "a continuous and sustained presentation of our industrial ability and our industrial ambitions through every available channel of communication open to us".
For this purpose, well-executed films are indispensable, but Sir Stephen presses for the art of national projection in a metaphorical as well as a literal sense. His proposal is that we should have a school of national projection-not as a government department, but rather as the result of private munificence-that must study national characteristics and achievements and lose no opportunity of suitably presenting these as records of fact to the wider world, through the medium of Press and poster, films and wireless, exhibitions and conferences. In these forms of enterprise, he complains that Britain has fallen behind some of the other great States of the world.

\section{Trevithick's First Rail Locomotive}

ON April 27, simultaneous meetings of the members of the Newcomen Society were held in London and New York. At both places, two papers were read, the first being by Mr. W. W. Mason on Trevithick's first rail locomotive, and the second by Mr. C. L. Chandler on early shipbuilding in Philadelphia. As the centenary of the death of Richard Trevithick would be commemorated next year, it seemed desirable, said Mr. Mason, to determine, so far as possible, the truth about the locomotive Trevithick built in 1803 and with which he experimented in South Wales in the early part of 1804 . Neither the account of the experiment in Francis Trevithick's "Life" of his father nor those contained in other works agree as to the design of the engine, while there are discrepan. cies in the drawings in existence. One account, for example, says the cylinder was placed vertically within the boiler, while Llewellyn's drawing, preserved in the Science Museum, shows the cylinder horizontal. But this is only one point which calls for further investigation. Whatever doubt may exist as to the arrangement of the engine, however, there is little question that on Feb. 21, 1804, it took a load of 10 tons of bar iron and about 70 passengers from the Penydarran works, where it was constructed, down the old tram-road to its junction with the Glamorganshire Canal at Abercynon, a distance of about 10 miles, and in March repeated the journey, but with a net load of 25 tons. One of the most versatile inventors of his age, Trevithick was a pioneer in the use of high pressure steam, and by his experiment in 1804 he became the father of the steam locomotive.

\section{Broadcast Reception in the United States}

IN World Radio for April 15 there is an interesting account of a motor tour by R. M. Bell in the United States with a portable receiving set. As good highways connect all parts of the country, the 3000-mile trip from the Atlantic seaboard to Los Angeles can be made quite easily. The tour brought within daylight range most of the American stations. In Chicago the 25 local stations made it difficult to hear outside stations. Doubtless the same difficulty arises in New York, which has 43 local stations. Near Chicago, a relay from Poznań came through in excellent volume. There are nine television stations at present 'on the air'. Chicago uses 45 lines per picture and 15 pictures per second, New York uses

No. 3262, VoL. 129] 
60 lines and 20 pictures per second. In Los Angeles, the 17 local broadcast stations, several of which are ' on the air' for 24 hours daily, made reception from other cities practically impossible, but a number of international relays from abroad were heard from them. The B.B.C. orchestra was heard as distinctly as it is in London. When passing through the Japanese and Mexican portion of the city, the street resounded with a speech from Berlin. In Tennessee, near Nashville, Los Angeles, 1775 miles to the west, and New York, 775 miles to the east, could be heard easily on the portable receiver. The writer mentions that Los Angeles (KFI), Dallas (WFAA), and Cincinnati (WLW) transmitted splendidly. In daytime they could be heard at a distance of 300 miles in good volume, and at night at distances of more than 1000 miles. When he got back to Pennsylvania, he heard at 7 A.M. the toasts given at the Lindbergh banquet at Tokyo (9 P.M. in Japan) being relayed from the local networks.

\section{U1tra-short Wave Television}

A sUCCESSFul public demonstration of ultra-short wave television was given on Friday, April 29, at Messrs. Selfridges' stores in Oxford Street, London. The transmitter was situated on the roof of the laboratories of Baird Television, Ltd., in Long Acre, W.C.2, the wave-length used being $6 \cdot 1$ metres. The ultra-short waves have the advantage over medium wave-lengths that they allow television pictures of much finer detail to be transmitted, and provide a reliable local service free from fading and atmospheric disturbances. An interesting feature of the transmission was that although sent out on ultra-short waves, the images could still be received easily by possessors of the ordinary Baird 'Televisor' and wireless sets of normal type designed for the present B.B.C. television transmissions. To do this, the only extra apparatus required was an ultra-short wave adaptor, which virtually converts any normal receiver into a super-heterodyne. The demonstration given on April 29 is the first public demonstration of the possibilities of ultra-short wave television to be given anywhere in the world, and marks a further stage in the development of the art.

\section{Developments in Methods of Communication}

A PAPER on modern communication systems, by Dr. F. Lüschen, was read to the Institution of Electrical Engineers on April 7. Dr. Lüschen pointed out that the rapid progress of invention has made modern communication systems very complicated to design. Few realise how difficult it was to solve the problem of the interconnexion of wired and wireless systems. This was first carried out in the telephone link between Great Britain and the United States. Further problems that have been solved are the multiple utilisation of lines for telegraphy and telephony, the control of electrical apparatus at a distance, and the electro-acoustic transmission problems involved in broadcasting and sound-films. These methods have widely extended the field of use of communication systems. The information contained in the spoken word is an extremely complicated function of the time. The transmission system is composed of widely different elements. At first, therefore, it appears to be a hopelessly difficult problem. Yet, with the help of a few simple mathematical principles, engineers have succeeded in visualising the transmission of signals. As an illustration of the pitch of perfection to which carriercurrent telephony has reached in the United States, Dr. Lüschen described a pole line carrying twenty pairs of conductors, sixteen of which carry three high frequency channels each, in addition to their low frequency communication circuits, while the other four pairs are equipped with ten telegraph channels each. Twenty pairs of wires thus result in 150 communication circuits, 80 of them being telegraph circuits and 70 of them telephone circuits. Dr. Lüschen also gave interesting particulars of tests made on a system of telephony and telegraphy linking Berlin with Buenos Aires. It is designed to transmit speech and two telegraphic messages simultaneously.

\section{Rival Theories of Hearing}

Is his Royal Institution discourse on Friday, April 29, on theories of hearing, Prof. H. Hartridge reminded his listeners that rivalry still exists between the theories of hearing, because the small size, the delicacy, and the inaccessibility of the internal ear make direct observation and experimentation wellnigh impossible. Some of the rival theories are the telephone theory, the modified telephone theory of Boring, the modified telephone theory of Watt, the volley theory of Wever and Bray, the pattern theory of Ewald, the stationary wave theory, and the resonance theory. At the present day, controversy principally centres round the resonance theory and some form of telephone theory. The production of deafness over a narrow range of frequencies, by surgical interference with a part of the internal ear, is accounted for more readily on the resonance theory than on the rival theory. The same may be said of boilermakers' deafness and its experimentally produced counterpart. When physical tests are applied to hearing, evidence is obtained in each case in favour of resonance and contrary to telephony. The universal acceptance of the resonance theory is delayed by various criticisms, which arise in most cases from unfamiliarity with the behaviour of resonators and sense organs. The resonance theory accounts satisfactorily for all the phenomena, and no other theory does this.

\section{Purpose in Evolution}

In the Riddell Memorial Lectures for 1931, delivered before the University of Durham at Armstrong College, Newcastle-on-Tyne, Sir J. Arthur Thomson discussed the general subject of "Purpose in Evolution" . (Oxford University Press, 1932, pp. 59, 2s. 6d. net). The opening lecture examined various aspects of Nature in view of the question: Is there a purpose in evolution? It grants that often the development and ways of acting of living units are purposive, and comes to the conclusion that the scientific facts do

No. 3262, VoL. 129] 